\title{
Atrazine levels in the Jaboticabal water stream (São Paulo State, Brazil) and its toxicological effects on the pacu fish Piaractus mesopotamicus
}

\author{
Edson Aparecido dos Santos ${ }^{1}$, Claudinei da Cruz ${ }^{1}$, Silvia Patrícia Carraschi ${ }^{1}$, José Roberto Marques \\ Silva ${ }^{2}$, Rafael Grossi Botelho ${ }^{3}$, Edivaldo Domingues Velini' ${ }^{2}$, and Robinson Antonio Pitelli ${ }^{1}$ \\ Universidade Estadual Paulista Júlio de Mesquita Filho - UNESP, Jaboticabal-SP', Universidade Estadual Paulista \\ Júlio de Mesquita Filho - UNESP, Botucatu-SP2, Centro de Energia Nuclear na Agricultura, Universidade de São \\ Paulo-CENA/USP, Piracicaba-SP3, Brazil
}

[Received in September 2014; CrossChecked in September 2014; Accepted in March 2015]

\begin{abstract}
The aim of this study was to determine the environmental concentration of atrazine (ATZ) in five streams located in the north of São Paulo state (Brazil) and evaluate its toxicological impact on young specimens of the pacu fish Piaractus mesopotamicus. Samples of water were collected on three occasions between 2010 and 2011, corresponding to periods signifying the beginning, middle, and end of rain season. ATZ levels were estimated by a high-performance liquid chromatography coupled with a mass spectrometry (HPLC-MS/MS) triple quadrupole. Later, the quotient of environmental risk $(\mathrm{QR})$ was determined based on the medium lethal concentration $\left(\mathrm{LC}_{50} 48 \mathrm{~h}\right)$, non-observable effect concentration (NOEC), and the estimated environmental concentration (EEC) of ATZ detected in the environment. Histological changes in gills and liver were also studied, along with the brain activity of the enzyme acetylcholinesterase (AChE). The highest concentration of ATZ measured was $10.4 \mu \mathrm{g} \mathrm{L}^{-1}$. The ATZ LC ${ }_{50}(48 \mathrm{~h})$ for young P. mesopotamicus was $24.46 \mathrm{mg} \mathrm{L}^{-1}$ and the QR was classified as "safe". Although the QR indicated that ATZ could be safe for the tested species, it caused many histological alterations in the liver and gills of the exposed specimens, and an increase in the AChE levels.
\end{abstract}

KEY WORDS: AChE; Gesaprim 500; herbicides; histology; HPLC-MS/MS; neotropical fish; toxicity

Brazilian agriculture is characterized by extensive pesticide use, with approximately 800,000 tonnes applied annually. The most frequently used are herbicides, which represent $60 \%$ of the total pesticide volume and $30 \%$ of their production costs $(1)$.

Atrazine (ATZ; 1-chloro-3-ethylamino-5isopropylamino-2,4,6-triazine) is an ionic herbicide with basic character, a solubility of $30 \mathrm{mg} \mathrm{L}^{-1}$, steam pressure of $3.9 \times 10^{-5} \mathrm{mPa}$, approximate half-life of 150 days, and sorption coefficient of $30 \mathrm{~cm}^{3} \mathrm{~g}^{-1}$ (2). Because of its wide utilisation and high mobilization in water-soil systems, ATZ is frequently detected in the aquatic environment by chromatographic techniques $(3,4)$.

Fish represent an excellent animal model to verify possible negative effects of chemicals in non-target organisms due to their capacity to metabolise and accumulate pollutants, participation in many inter-relations in the food chain and sensitivity towards pollutants (5). They are also widely distributed in the environment, which is extremely important for a test organism expected to serve as a representative of an ecosystem (5).

Correspondence to: Rafael GrossiBotelho,Laboratório deEcotoxicologiaAquática, Avenida Centenário, 303, 13416-000, São Dimas, Piracicaba-SP, Brasil, E-mail: rbotelho@cena.usp.br
The pacu fish Piaractus mesopotamicus is a Brazilian endemic species widely distributed in large hydrographic basins, and frequently found in waters near agrosystems (6). It has been largely used in ecotoxicological studies in Brazil $(7,8)$, for instance in evaluating the effects of chemicals on cholinesterase activity $(8,9)$ and the tissue histopathology (10).

Environmental monitoring and assessments of potentially harmful effects that chemicals released into the environment may have are fundamental for gaining a full image of the environmental dynamics of pesticides after utilization. Although experiments with ATZ have been conducted for a long time using different species of aquatic organisms worldwide, which even resulted with the ban of its use in the European Union in 2004 (11), in many regions, including Brazil, ATZ is still one of the most widely used herbicides. It is therefore especially important to continue ecotoxicological studies on ATZ since the herbicide and its residues are still detected as persistant contaminants of aquatic environments. Along these lines, the objective of present study was to determine and quantify ATZ levels in five streams located in the north of the São Paulo state (Brazil) using HPLC-MS/MS and evaluate their effects by studying several biomarkers in young P. mesopotamicus. 
We also calculated the quotient of environmental risk $(\mathrm{QR})$ of ATZ on the tested species.

\section{MATERIALS AND METHODS}

\section{Study area and sampling period}

The study area encompassed five streams belonging to the micro hydrographic basin of Corrego Rico (Jaboticabal, São Paulo, Brazil), located at an area with intensive agriculture and cultivation of sugarcane, peanuts, corn, citrus, guava, vegetables, and soybean (12).

Water samples were collected at one point of each stream on three different occasions (November 29, 2010; February 1, 2011; and May 9, 2011), representing the beginning, middle, and end of rain season. All of the sampling points were georeferenced.

Water samples were collected on the surface and in the middle of the stream, forming a sample of $200 \mathrm{~mL}$. After collection, samples were refrigerated and transported immediately to the laboratory where further analyses were performed.

\section{Chromatographic analyses}

The analyses were conducted at the Nucleo de Pesquisas Avançadas em Matologia (NUPAM) laboratory of the Faculdade de Ciências Agronômicas - FCA at the Universidade Estadual Paulista Julio de Mesquita Filho - UNESP campus in Botucatu immediately after sampling.

\section{Solvents and chemical reagents}

The analytical standard of ATZ (99.8 \%) was purchased from Sigma-Aldrich (St. Louis, MO, USA). To prepare the mobile phase, methanol and acetic acid (99.0\%) were used, both purchased from Sigma-Aldrich (St. Louis, MO, USA).

\section{Equipment, sample preparation, and chromatographic conditions}

A total of $1.5 \mathrm{~mL}$ of each sample was filtered (filter $0.45 \mu \mathrm{m}$ Millex HV - Millipore, Darmstadt, Germany) prior to analysis with a UFLC Prominence LC-MS/MS triple quadrupole system (Shimadzu, Kyoto, Japan) equipped with a dual pump LC-20AD, a vacuum degasser DGU20A5, an autosampler SIL-20AC, controller system CBM20A, and column heater-cooler CTO-20A. Chromatographic separations were performed through a $\mathrm{C}_{18}$ column (Synergi $2.5 \mu$, Fusion RP $100 \AA$, and 50x4.6 mm). The flow used was of $0.4 \mathrm{~mL} \mathrm{~min}^{-1}$ with an injection volume of $30 \mu \mathrm{L}$. The mobile phase consisted of methanol and water, both acidified with $0.5 \%$ of acetic acid (eluent $A$ and eluent $B$, respectively), with the following gradient program: 0-8 min from $20 \%$ to $95 \%$ of A, $8-12$ min $95 \%$ of A (isocratic hold), 12-15 min reconditioning to initial conditions. The total runtime was 19 min.

\section{Mass spectrometry}

After separation in the chromatographic system, a hybrid triple-quadrupole mass spectrometer, model 3200 Q TRAP(Applied Biosystems Sciex, Foster City, CA, USA) was used. The monitored transitions of ATZ were $216.24 \rightarrow 174.2,216.24 \rightarrow 68.1$, and $216.24 \rightarrow 104.1$.

\section{Linearity and limit of detection and quantification}

The linearity of the method was determined through injection of eight concentrations of ATZ herbicide in triplicate: $0.391 ; 0.781 ; 1.56 ; 3.13 ; 6.25 ; 12.5 ; 25$, and $50 \mu \mathrm{g} \mathrm{L}^{-1}$. The limit of detection was determined from the mean values of the blank samples (seven replicates) plus three times the standard deviation of the blank samples. The limit of quantification was determined from the mean values of blank samples (seven replicates) plus ten times the standard deviation of blank samples.

\section{Maintenance of fish}

For the maintenance and conduction of toxicity tests, NBR 15088 guidelines from the Brazilian Technical Standard Association (13) were followed. Young specimens of Piaractus mesopotamicus (Holmberg, 1887) with weight approximately $16.5 \mathrm{~g}$ were obtained from the Center of Aquaculture at the Universidade Estadual Paulista Júlio de Mesquita Filho campus in Jaboticabal (Brazil).

Fish were kept in a polyethylene tank (200 L) filled with dechlorinated water, with continuous aeration (dissolved oxygen 7.0-7.5 mg L-1, pH 7.1-7.8, conductivity 125$130 \mu \mathrm{S} \mathrm{cm}^{-1}$, and hardness 33-50 as $\mathrm{CaCO}_{3}$ ) for a period of ten days. During this acclimation period, fish were fed $\mathrm{ad}$ libitum with fish food. The temperature of the room was $27 \pm 2{ }^{\circ} \mathrm{C}$ and the photoperiod comprised $12 \mathrm{~h}$ of light and $12 \mathrm{~h}$ of darkness. A sensibility test (14) was conducted with potassium chloride $(\mathrm{KCl})$ as the reference substance to verify the health of the organisms.

\section{Toxicity tests on fish}

For the acute toxicity test with ATZ, a preliminary assay was carried out to determine the concentrations to be used in the definitive test. It involves the concentrations: 15, 20, 25,35 , and $45 \mathrm{mg} \mathrm{L}^{-1}$, obtained from the commercial product Gesaprim 500 CIBA-GEIGY ${ }^{\circledR}$ (Syngenta, Basel, Switzerland), which contains $500 \mathrm{~g} \mathrm{~L}^{-1}$ of ATZ in concentrated suspension. For each concentration, three replicates were established, with five organisms in each. The control, non-treaded, group of fish was kept in parallel. To prepare the test solutions with given concentrations, the same maintenance water was used. The test was conducted in a static system (without renovation of test solution) in $10 \mathrm{~L}$ glass aquariums (filled with $7 \mathrm{~L}$ of test solution) with artificial aeration for $48 \mathrm{~h}$ and without feed. Later, the $\mathrm{LC}_{50}$ (48 h) was determined using the Trimmed Spearman-Karber method (15). 
After the determination of $\mathrm{LC}_{50}(48 \mathrm{~h})$, a subacute toxicity test was performed where the fish were exposed to the following concentrations of ATZ for 7 days: $\mathrm{LC}_{50} / 100$, $\mathrm{LC}_{50} / 50, \mathrm{LC}_{50} / 10$, and $\mathrm{LC}_{50} / 5$, corresponding to 0.265 ; $0.530 ; 2.650$, and $5.290 \mathrm{mg} \mathrm{L}^{-1}$, respectively. Controls were kept in parallel. Three replicates were used for each tested concentration with five organisms in each one. The test was conducted in static system, although the fish were fed with commercial diets on the $1^{\text {st }}, 3^{\text {rd }}, 5^{\text {th }}$, and $7^{\text {th }}$ day. During the subacute and acute exposure, the behaviour of organisms was evaluated by monitoring agitation, opercular beat rate, gasping ability, lethargy, and search for oxygen, water column dispersion, and spasms (5).

\section{Determination of the quotient of environmental risk $(Q R)$}

$\mathrm{LC}_{50}$ values, estimated environmental concentration (EEC), and non-observable effect concentration (NOEC) were used to determine the $\mathrm{QR}$.

According to Urban and Cook (16), the contaminant presents risk without any adverse effect if $\mathrm{QR} \leq 0.1$; risk with the possibility of adverse effect if $0.1 \leq \mathrm{QR} \leq 10$, and risk with the probability of adverse effect if $\mathrm{QR}>10$. According to Goktepe et al. (17), the contaminant presents a high risk if $\mathrm{QR}>0.5$, medium risk if $0.05 \leq \mathrm{QR} \leq 0.5$, and low risk if $\mathrm{QR}<0.05$. Both authors determined the $\mathrm{QR}$ using the relation $\mathrm{EEC} / \mathrm{LC}_{50}$. According to the Commission of the European Communities (18), the QR is equal to EEC/NOEC and there is risk of intoxication if $\mathrm{QR}>1$.

\section{Histological analyses in gills and liver}

For the histological evaluation of gills and liver, the organisms that survived in the acute and subacute test were used.

Five animals per each concentration were euthanized. The second gill arch and the liver were dissected and immersed in $0.1 \mathrm{~mol} \mathrm{~L}^{-1}$ formaldehyde fixative ( $\mathrm{pH} 7.2$ ) for $24 \mathrm{~h}$. Subsequently, the samples were subjected to dehydration with alcohol $(70,80,90$, and $100 \%$ ethanol), diaphanization in xylol, and immersion in plastic paraffin (Histosec ${ }^{\circledR}$ Merck, Darmstadt, Germany). Sections of $5 \mu \mathrm{m}$ in thickness were acquired through automatic microtome (Leica, RM-2155, Deerfield, IL, USA) and stained with hematoxylin and eosin. Microscopic analyses were performed using an Axiovert 35 microscope (Zeiss, Oberkochen, Germany) under 1000x magnification, and the images were acquired using an Axiocam ICc3 camera.

\section{Activity of AChE, sources of chemicals}

AChE activity was studied in fish that survived the acute toxicity test. After collection, fish brains were stored at $-80{ }^{\circ} \mathrm{C}$ until analysis. After thawing, samples were homogenised in $150 \mathrm{mmol} \mathrm{L}^{-1} \mathrm{NaCl}(15 \mathrm{~mL})$ using PotterElvejhem glass/Teflon homogenizer (Thomas Scientific, Swedesboro, NJ). The homogenates were centrifuged for $15 \mathrm{~min}$ at $3000 \mathrm{~g}$ at $5^{\circ} \mathrm{C}$ (centrifuge, Beckman J2-HS,
Ramsey, Minnesota) and the supernatant was used as the enzyme source. AChE activity was measured as described by Ellman et al. (19) and modified by Villescas et al. (20). Aliquots of the supernatant $(50 \mathrm{~mL})$ were incubated at $25^{\circ} \mathrm{C}$ for 2 min with $0.1 \mathrm{~mol} \mathrm{~L}^{-1}$ phosphate buffer $(\mathrm{pH} 7.5)$ and $1 \mathrm{mmol} \mathrm{L}^{-1}$ dithiobisnitrobenzoic acid (DTNB). After $2 \mathrm{~min}$, the reaction was initiated by the addition of acethylthiocholine $\left(0.08 \mathrm{~mol} \mathrm{~L}^{-1}\right)$ as substrate for the reaction mixture. The final volume was $2.0 \mathrm{~mL}$. Absorbance was determined at $412 \mathrm{~nm}$ during $2 \mathrm{~min}$ (microplate absorbance reader, Männedorf, Switzerland). The measured activity was expressed as $\mu \mathrm{mol} \mathrm{min} \mathrm{mg}^{-1} \mathrm{mg}^{-1}$ protein. All values are represented as mean \pm standard deviation (SD) . Statistical evaluations of the differences between AChE activity in groups treated with ATZ and control were performed using one-way analysis of variance (ANOVA) followed by Tukey's test. Prior to the analyisis, homogeneity of data was verified by Hartley's homogeneity of variance test (21). Data were analysed using SAS software version 9.2 (SAS Institute Inc, Cary, NC, USA). $P$ values of less than 0.05 were considered statistically significant.

\section{RESULTS AND DISCUSSION}

\section{Linearity and limit of detection and quantification}

The method used for ATZ detection in the water samples presented linearity, since the correlation coefficient was higher than 0.99 . The range of recovery values were between 70 and $120 \%$ and precision was less than $30 \%$. The equation of linearity was determined by $y=6580 x-432$ and the limits of detection and quantification were: 0.130 and $0.391 \mu \mathrm{g} \mathrm{L}^{-1}$ of ATZ, respectively.

\section{Concentrations of ATZ in streams}

The concentrations of ATZ found during the period of study and the geographic position of each sampling site are presented in Table 1. The Brazilian Environment National Council, represented by CONAMA through Resolution 357 of 2005, establishes the maximum allowed values for a huge variety of chemical agents, among them also ATZ, in aquatic environments. The maximum limit of ATZ in Brazilian aquatic environments is $2 \mu \mathrm{g} \mathrm{L}^{-1}(22)$. This study established a concentration of $10.4 \mu \mathrm{g} \mathrm{L}^{-1}$ in stream 4 (Table 1), five times greater than allowed by the legislation. This concentration was detected in the sample collected in November, probably due to a lower volume of accumulated rains until this month, when compared with the precipitation prior to February or May (Figure 1). During rain season, the surface runoff is the main way of entrance of chemical agents in the aquatic environment; however, due to the dilution of contaminants, the concentrations are usually low. It was surprising to us how such a high concentration could be observed in November. We concluded that the possible source of contamination could be the application 
Table 1 Geographic position of the sampling sites located in the hydrographic watershed of the study area and atrazine (ATZ) levels detected in five streams by HPLC/MS-MS

\begin{tabular}{|c|c|c|c|c|}
\hline \multirow{2}{*}{ Stream } & \multirow{2}{*}{ Geographic position of the sampling sites } & \multicolumn{3}{|c|}{ ATZ levels $\left(\mu g \mathbf{L}^{-1}\right)$} \\
\hline & & Nov 2010 & Feb 2011 & May 2011 \\
\hline Stream 1 & $21^{\circ} 16^{\prime} 20.74^{\prime \prime} \mathrm{S} \quad 48^{\circ} 23^{\prime} 43.58^{\prime \prime} \mathrm{W}$ & ND & ND & ND \\
\hline Stream 2 & $21^{\circ} 18^{\prime} 50.49^{\prime \prime} \mathrm{S} 48^{\circ} 26^{\prime} 91.18^{\prime \prime} \mathrm{W}$ & $<\mathrm{LOQ}$ & ND & ND \\
\hline Stream 3 & $21^{\circ} 16^{\prime} 47.65^{\prime \prime} \mathrm{S} \quad 48^{\circ} 25^{\prime} 02.24^{\prime \prime} \mathrm{W}$ & $<$ LOQ & ND & $<$ LOQ \\
\hline Stream 4 & $21^{\circ} 17^{\prime} 48.70^{\prime \prime} \mathrm{S} 48^{\circ} 25^{\prime} 31.50^{\prime \prime} \mathrm{W}$ & 10.4 & ND & ND \\
\hline Stream 5 & $21^{\circ} 19^{\prime} 08.81^{\prime \prime} \mathrm{S} \quad 48^{\circ} 23^{\prime} 57.15^{\prime \prime} \mathrm{W}$ & $<$ LOQ & ND & ND \\
\hline
\end{tabular}

$N D=$ not detected

$L O Q=$ limit of quantification

of ATZ by air (aeroplanes). ATZ is commonly used in late post-emergence, to control weeds in sugarcane at the time of harvest. In some cases, due to irregular distribution of weeds (like those in the Convolvulacea family), which make mechanical harvest difficult, herbicides are sprayed by planes, which might result in their unwanted disposal into non-target environments.

Our assumption was additionally supported by the results of previous studies performed in the same study area. Pissarra et al. (23) and Donadio et al. (24) reported that the study area had no riparian forests along the streams, tillage systems with harrowing, or ploughing in downhill areas and no practices were employed to prevent erosions. Furthermore, significant amounts of herbicides are released into streams due to deficiencies in operational techniques, non-attention to weather conditions, details related to the disposal of pesticide containers, and poor conditions of the equipment used for their application.

It is also important to consider that the ATZ residuals can also come from other regions. According to Gish et al. (25), the loss of this herbicide to the atmosphere can be higher than the loss due to leaching or surface runoff; besides this, $12 \%$ of this herbicide can volatilise and deposit in regions far from the application sites.

Herbicides from the class of triazines were previously determined in other aquatic environments in the São Paulo state. In a study by Armas et al. (26), the Corumbatai River was monitored for the presence of the amounts of herbicides using HPLC/UV-vis. In this study, concentrations of ametryne and ATZ varied from 0.7 to $2.9 \mu \mathrm{g} \mathrm{L}^{-1}$ and 0.6 to $2.7 \mu \mathrm{g} \mathrm{L}^{-1}$, respectively. ATZ concentrations were also found in other rivers in Brazil, as reported by Azevedo et al. (27) in the Paraíba do Sul Ríver $\left(0.231 \mu \mathrm{g} \mathrm{L}^{-1}\right)$ and Bortoluzzi et al. (28) in surface waters located at Agudo Basin $\left(0.48 \mu \mathrm{g} \mathrm{L}^{-1}\right)$, Arvorezinha Basin $\left(0.82 \mu \mathrm{g} \mathrm{L}^{-1}\right)$, and at Cristal $\operatorname{Basin}\left(0.13 \mu \mathrm{g} \mathrm{L}^{-1}\right)$.

Acute and subacute toxicity and environmental risk of ATZ to P. mesopotamicus

The $\mathrm{LC}_{50}(48 \mathrm{~h})$ of $\mathrm{KCl}$ determined for P. mesopotamicus was of $1.54 \mathrm{~g} \mathrm{~L}^{-1}$, varying between 1.37 and $1.70 \mathrm{~g} \mathrm{~L}^{-1}$, i.e. within the acceptable limit determined by the ABNT (13). The $\mathrm{LC}_{50}(48 \mathrm{~h})$ of ATZ for young P. mesopotamicus was determined to be $26.46 \mathrm{mg} \mathrm{L}^{-1}$, with inferior and superior

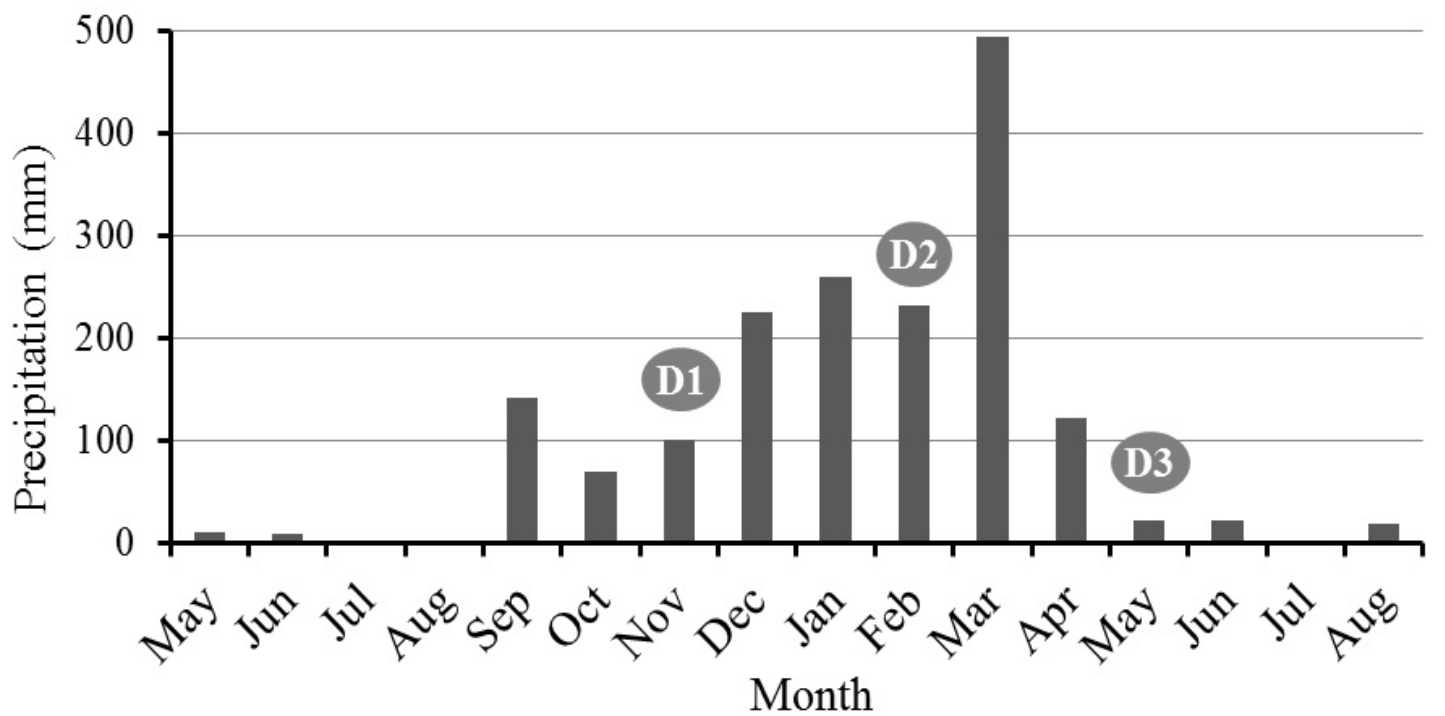

Figure 1 Total precipitation in the hydrographic watershed of the study area (Brazil) during May 2010 to August 2011. Dates of sampling: D1: Nov 29, 2010, D2: Feb 1, 2011, D3: May 9, 2011 
limits of 22.69 and $30.85 \mathrm{mg} \mathrm{L}^{-1}$, respectively. During the acute exposure, concentrations of up to $15 \mathrm{mg} \mathrm{L}^{-1}$ did not cause mortality in the exposed organisms. On the other hand, 33, 44, 67, and $100 \%$ mortality occurred at 20, 25, 35 , and $45 \mathrm{mg} \mathrm{L}^{-1}$, respectively, which demonstrates the lethality in a dose-dependent manner (Figure 2).

The $\mathrm{LC}_{50}(48 \mathrm{~h})$ of ATZ was previously established in other fish species. Kreutz et al. (29) estimated $10.2 \mathrm{mg} \mathrm{L}^{-1}$ for the South American catfish (Rhamdia quelen) while Solomon et al. (30) determined $100 \mathrm{mg} \mathrm{L}^{-1}$ for the Crucian carp (Carassius carassius). In another study, Botelho et al. (31) determined $5.02 \mathrm{mg} \mathrm{L}^{-1}$ for the Nile tilapia (Oreochromis niloticus).

During the subacute exposure, mortality was not observed in organisms exposed to the tested concentrations of ATZ or in the control group. However, this does not mean that the product is not toxic to the tested species in the evaluated concentrations, since physiological and biochemical modifications were observed at the sublethal concentrations.

With regard to the behaviour, at acute exposure, all fish exposed to each of the tested concentration presented higher opercular beat rate, agitation, and changes in skin colour; however, only those exposed to $45 \mathrm{mg} \mathrm{L}^{-1}$ exhibited search for oxygen. Besides this, other signals of intoxication occurred, like water column imbalance, lethargy, spasms, and oral haemorrhage. The spasms were visible in all of the exposed fish. In the subacute test, only agitation and modifications in skin colour were observed in fish exposed to $5.29 \mathrm{mg} \mathrm{L}^{-1}$ of ATZ.

According to Chovanec et al. (5), modification of behaviour is common in fish exposed to herbicides in water and modification of skin colour is an indication of stress by diverse contaminations. At $6.0 \mu \mathrm{g} \mathrm{L} \mathrm{L}^{-1}$, ATZ caused disturbances in Danio rerio and Carassius auratus (32).
$Q R$

The results of $Q R$ are presented in Table 2. To determine the QR, we used $5.29 \mathrm{mg} \mathrm{L}^{-1}$ of ATZ, i.e. the higher concentration tested in the subacute exposure (considering the fact of non-occurrence of mortality during the period of subacute exposure, which made the determination of the NOEC impossible. According to Urban and Cook (16), the obtained results suggest that ATZ presents risk but with no adverse effect on the evaluated species. However, according to Goktepe et al. (17), this herbicide presents a low risk to P. mesopotamicus. Finally, according to CEC (18), ATZ does not present a risk of intoxication to the evaluated species at the tested concentrations. Thus, it can be concluded that the concentrations of ATZ found in studied water streams were safe for P. mesopotamicus, irrespective of the calculation methodology.

\section{Histopathological evaluations of gills and liver}

The contaminants present in aquatic environments can induce irreversible damage in many organs of exposed fish. Gills and livers are main targets of toxic agents, since they are responsible for respiration, ionic regulation, and excretion and also take critical part in the biotransformation of chemicals, respectively. These organs have been frequently used as biomarkers of exposure to xenobiotics (33) and in the evaluation of aquatic environment quality (34).

The most prominent histological alterations in gills of young P. mesopotamicus observed in this study after ATZ exposure are shown in Figure 3. No alterations were observed in gills of the control group. However, in fish acutely exposed to concentrations of $15-25 \mathrm{mg} \mathrm{L}^{-1}$ we observed interlamellar space reduction and fusion of secondary lamellae. In fish exposed to concentrations higher

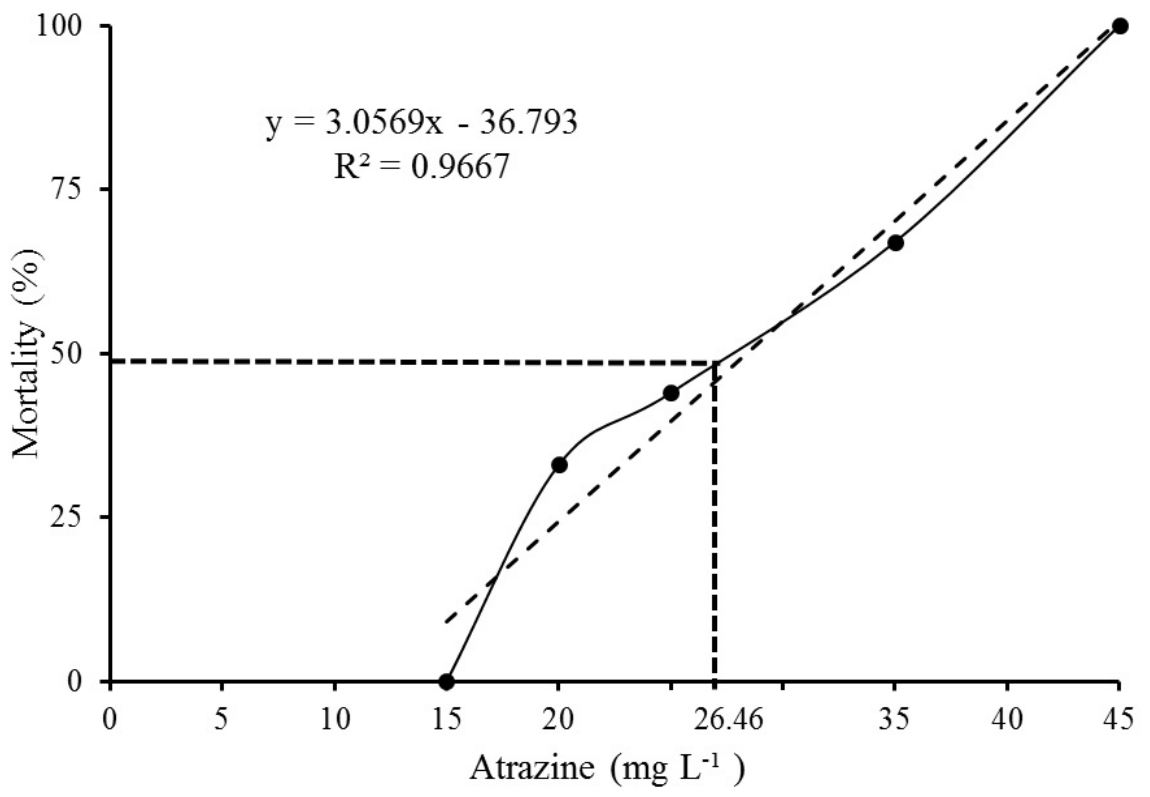

Figure 2 Acute toxicity of atrazine for young P. mesopotamicus 
Table 2 Quotient of environmental risk $(Q R)$ of atrazine for young of $\mathrm{P}$. mesopotamicus compared with the literature

\begin{tabular}{ccccc}
\hline Formula & Calculation & QR & Definition & Source \\
\hline$\frac{\mathrm{EEC}}{\mathrm{LC}_{50}(48 \mathrm{~h})}$ & $\frac{10.4}{26.46}$ & 0.0004 & $\begin{array}{c}\text { Atrazine presents risk } \\
\text { without any adverse effect. }\end{array}$ & $\begin{array}{c}\text { Urban and Cook } \\
(19)\end{array}$ \\
\hline$\frac{\mathrm{EEC}}{\mathrm{LC}}(48 \mathrm{~h})$ & $\frac{10.4}{26.46}$ & 0.0004 & Atrazine presents low risk & Goktepe et al. (20) \\
\hline$\frac{\mathrm{EEC}}{\mathrm{NOEC}}$ & $\frac{10.4}{5.29}$ & 0.0020 & $\begin{array}{c}\text { Atrazine does not present } \\
\text { risk of intoxication }\end{array}$ & CEC (21) \\
\hline$L C_{50}=$ medium lethal concentration; NOEC=non-observable effect concentration; EEC=estimated environmental concentration
\end{tabular}

than $35 \mathrm{mg} \mathrm{L}^{-1}$, apart from all the alterations already mentioned, epithelial lifting, subepithelial oedema, and blood stasis were observed.

Subacute exposure of fish to ATZ resulted with a few alterations in the gills. In these fish only blood stasis and decrease in the interlamellar space was observed when exposed to 2.65 and $5.29 \mathrm{mg} \mathrm{L}^{-1}$ of ATZ.

The existing literature confirms the occurrence of gill alterations following ATZ exposure $(35,36)$. Because of the vital importance of this organ, any damage could reflected on the behaviour of fish, mainly related to respiratory damages like search for oxygen and oral prolapse, beyond the difficulty of maintenance and movement in the water column (32).

Among the many forms of gill defence mechanisms against the entrance of pathological microorganisms and chemical agents, the decrease in interlamellar space manifested by the fusion of secondary lamellae is the most prominent, forming a protection against the entrance of contaminants in the capillary blood (37). Once the contaminant persists in the gills, several symptoms of intoxication are observed, like subepithelial oedema in secondary lamellae observed in fish exposed to concentrations of $45 \mathrm{mg} \mathrm{L}^{-1}$ of ATZ.

Histopathological changes in the liver which occurred after ATZ exposure are presented in Figure 4. The most frequent was the increase in the diameter of sinusoidal capillaries. According to Solomon et al. (30), this alteration can be an indication of an increase in blood flow in the region of contamination with the intention of faster elimination or metabolisation of the chemical agent.
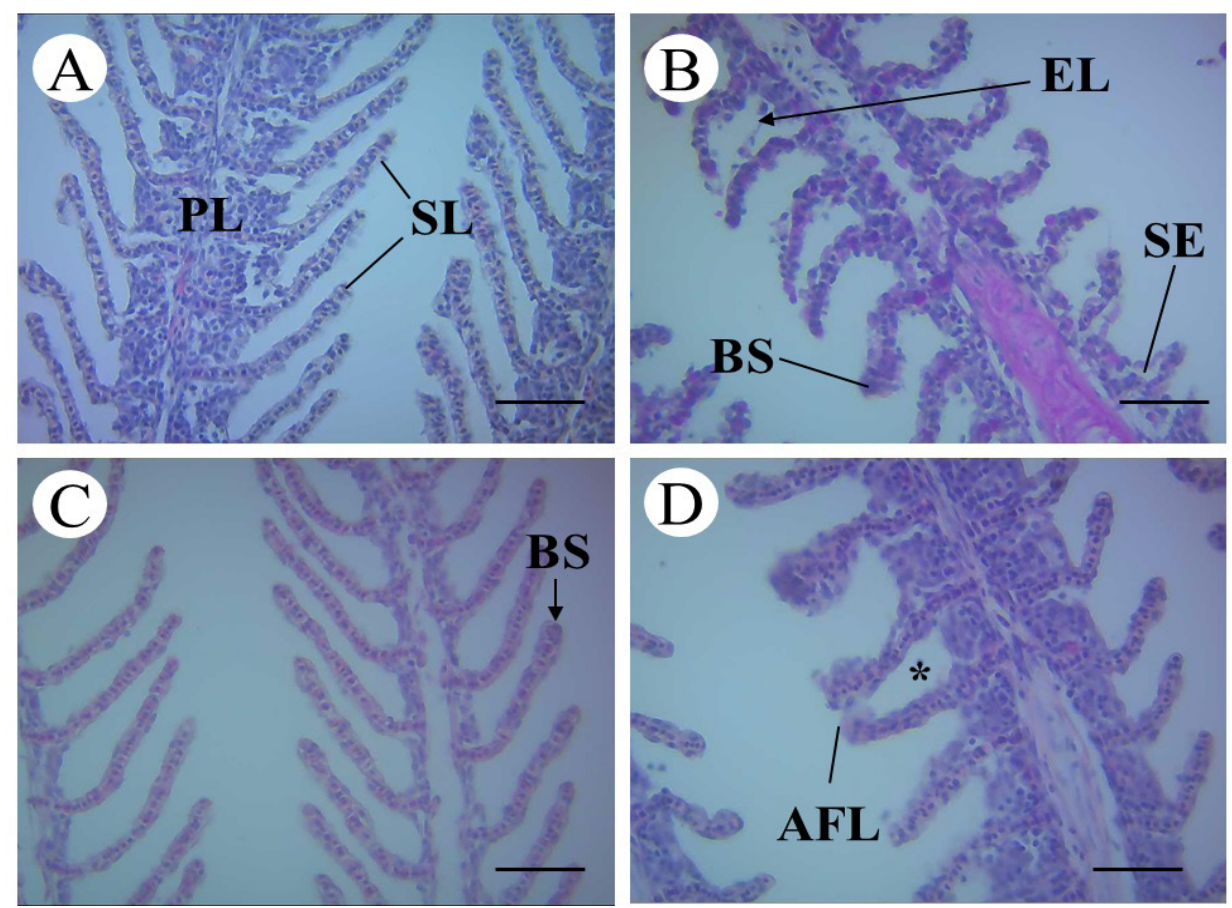

Figure 3 Longitudinal sections of gills of $\mathrm{P}$. mesopatamicus exposed to atrazine. A: organization of primary (PL) and secondary lamellae (SL) of the control group. B: epithelial lifting (EL), subepithelial oedema (SE), and blood stasis (BS) in fish exposed to concentrations above $35 \mathrm{mg} \mathrm{L} \mathrm{L}^{-1}$ for $48 \mathrm{~h}$. C: blood stasis (BS) in fish exposed to 2.65 and $5.29 \mathrm{mg} \mathrm{L} \mathrm{L}^{-1}$ for 7 days. D: interlamellar space reduction (*) and apical fusion of lamellae (AFL) in fish exposed to 15 and $25 \mathrm{mg} \mathrm{L^{-1 }}$ for $48 \mathrm{~h}$. Stained with hematoxylin and eosin. Scale bar $=50 \mu \mathrm{m}$ 

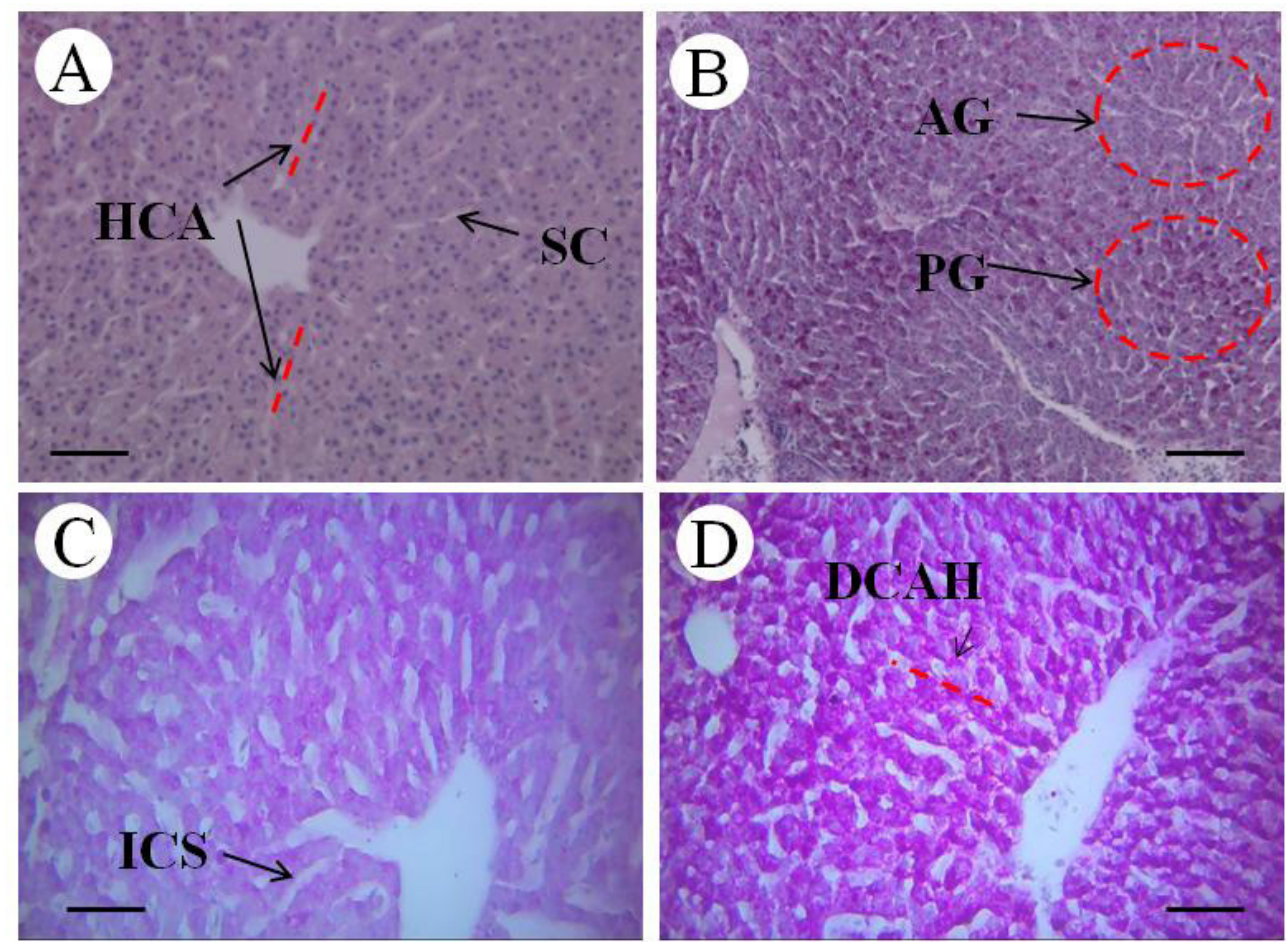

Figure 4 Transversal sections of the liver of P. mesopotamicus exposed to ATZ. A: organization of hepatocytes in cordonal arrangement (HCA) and sinusoidal capillary (SC) of the control group. B: hepatocytes with absence (AG) and presence of glycogen (PG) in fish exposed to concentrations higher than $25 \mathrm{mg} \mathrm{L} L^{-1}$ for $48 \mathrm{~h}$. C: increasing the diameter of the capillary sinusoid (ICS) in fish exposed to $5.29 \mathrm{mg} \mathrm{L}^{-1}$ for 7 days. D: disorganization in the cordonal arrangement of hepatocytes (DCAH) in fish exposed to 0.265 and $0.530 \mathrm{mg} \mathrm{L^{-1 }}$ for 7 days. Stained with hematoxylin and eosin. Scale bar $=50$ um

In normal conditions, the liver of $P$. mesopotamicus consists of sinusoidal capillaries and hepatocytes in a characteristic cordonal arrangement. The hepatocytes have a hexagonal shape with an evident cytoplasm and nuclei with marginal position as observed in the control group (Figure 4A).

In hepatocytes of fish acutely exposed to concentrations of ATZ higher than $25 \mathrm{mg} \mathrm{L}^{-1}$, we observed absence and loss of glycogen. These results are in accordance with the results of Dornelles and Oliveira (38) on Lithobates catesbeianus who established a $>90 \%$ decrease in glycogen levels in the liver and gills of tadpoles exposed to 5, 10, and $20 \mu \mathrm{g} \mathrm{L}^{-1}$ of ATZ for 7 and 14 days.

Subacute exposure to 0.265 and $0.530 \mathrm{mg} \mathrm{L}^{-1}$ of ATZ resulted with disorganisation in the cordonal arrangement of hepatocytes, while the increase in diameter of sinusoidal capillary was observed after exposure to $5.29 \mathrm{mg} \mathrm{L}^{-1}$ of ATZ (Figure $4 \mathrm{C}$ and D).

The process of biotransformation of ATZ occurs due to an increase in enzymatic activity, which provokes displacement in the cellular nuclei and hepatocytes hypertrophy (5). Furthermore, the metabolism consumes glycogen, mainly in regions next to the capillaries, near the first contact of a xenobiotic with an organ, and thus it is possible to consider a different amount of glycogen according to the position of hepatocytes in the function of sinusoidal capillary, like that observed in fish exposed to concentrations above $25 \mathrm{mg} \mathrm{L}^{-1}$ of ATZ.

\section{AChE activity}

Our results show that ATZ influenced the amount of hydrolysed acetylcholine in the brain. Regardless of the concentration, fish exposed to this herbicide presented about $50 \%$ more AChE activity in relation to the control group (Figure 5). In the present study, the increase of AChE levels was a response to a stressful toxicological situation. Animals could compensate stress by enhancing AChE activity, which was described previously (39).

Some herbicides act as AChE inhibitors of in fish. For instance, sublethal concentrations of diuron and nicosulfuron caused more than $50 \%$ of $\mathrm{AChE}$ inhibition after a 48 -h exposure of young C. auratus (40). Similarly, in a study by Miron et al. (41), fingerlings of Rhamdia quelen exposed to clomazone presented up to an $83 \%$ decrease in brain $\mathrm{AChE}$ activity. Lowering of $\mathrm{AChE}$ leads to the accumulation of acetylcholine in central colinergic synapse which results with muscular dysfunctions (32). Miron et al. (41) also observed an increase of 98 and $173 \%$ in the AChE activity in fish exposed to the herbicides quinclorac and metsulfuronmethyl, which suggests that the stimulatory and inhibitory effects of AChE can cause similar results in the cholinergic neurotransmission process. 


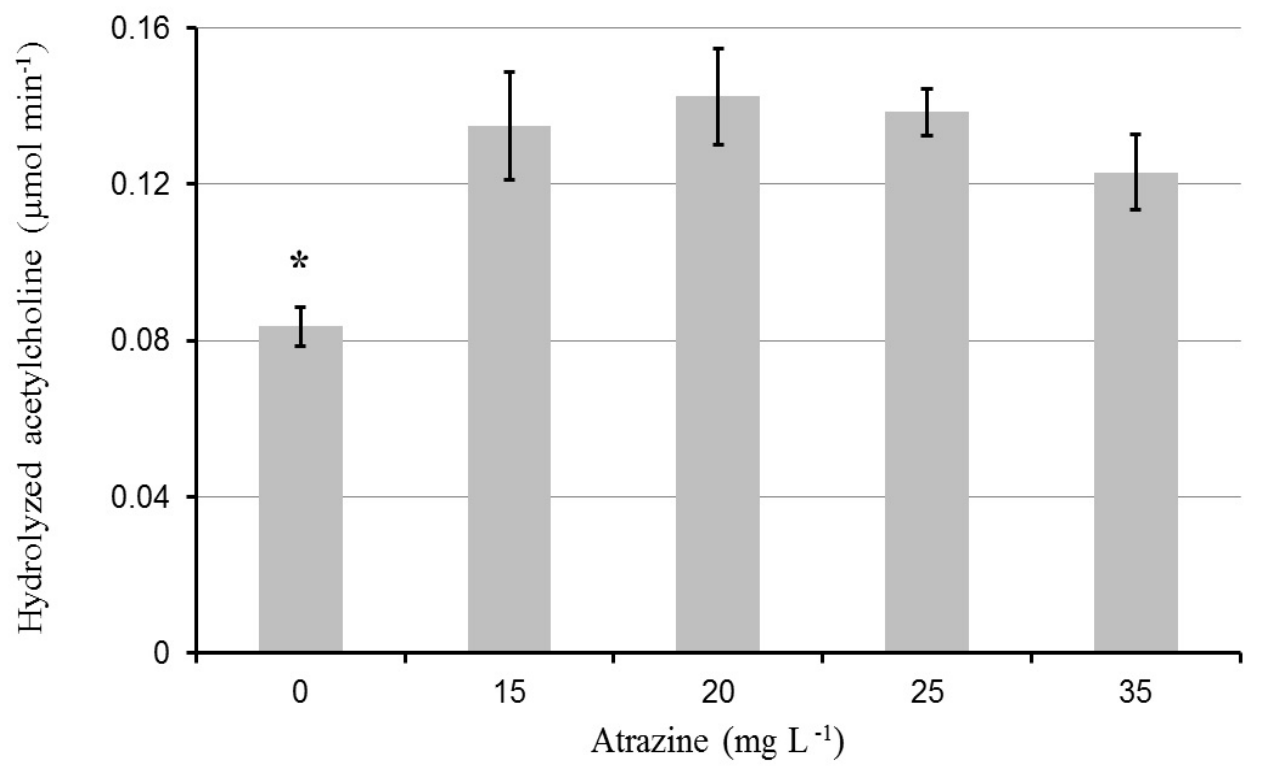

Figure 5 Acetylcholine hydrolyzed (micromol $\mathrm{min}^{-1} \mathrm{mg}^{-1}$ protein) in the brain of P. mesopotamicus after acute exposure to atrazine for $48 \mathrm{~h}$. *Significantly different as compared to the control group $(\mathrm{P}<0.05$; Tukey's test)

\section{CONCLUSION}

Taken together, our results show that only one out of the five studied streams had ATZ concentrations greater than allowed by the CONAMA for aquatic environments. The $\mathrm{LC}_{50}(48 \mathrm{~h})$ for ATZ established in laboratory conditions on young $P$. mesopotamicus was $26.46 \mathrm{mg} \mathrm{L}^{-1}$, and according to the QR, ATZ was classified safe for the tested species. The occurrence of different gill and liver histopathological alterations as well as increased brain acetylcholinesterase activity after exposure to ATZ indicate that $P$. mesopotamicus could be considered an appropriate species for monitoring of the adverse effects of ATZ.

\section{Acknowledgements}

This study was supported by the National Council for Scientific and Technological Development

\section{Conflict of interest}

The authors declare no conflict of interest

\section{REFERENCES}

1. Gianessi PL. The increasing importance of herbicides in worldwide crop production. Pest Manag Sci 2013;69:1099105. doi: $10.1002 /$ ps.3598

2. Rodrigues BN, Almeida FS. [Guia de herbicidas, in Portuguese]. Londrina: IAPAR/GTL; 2005.

3. Benvenuto F, Marín JM, Sancho JV, Canobbio S, Mezzanotte V, Hernández F. Simultaneous determination of triazines and their main transformation products in surface and urban wastewater by ultra-high-pressure liquid chromatography- tandem mass spectrometry. Anal Bioanal Chem 2010;397:2791-805. PMID: 20658761

4. García-Galán MJ, Díaz-Cruz MS, Barceló D. Determination of triazines and their metabolites in environmental samples using molecularly imprinted polymer extraction, pressurized liquid extraction and LC-tandem mass spectrometry. J Hydrol 2010;383:30-8. doi: 10.1016/j.jhydrol.2009.09.025

5. Chovanec A, Hofer R, Schiemer F. Fish as bioindicators. In: Markert BA, Breure AM, Zechmeister HG, editors. Bioindicators and biomonitors - principles, concepts and applications. Amsterdam: Elsevier; 2003. p. 639-76.

6. Balen RE, Tetu PN, Bombardelli RA, Pozza PC, Meurer F. Digestible energy of crude glycerol for pacu and silver catfish. Cienc Rural 2014;44:1448-51. doi: http://dx.doi. org/10.1590/0103-8478cr20131426

7. Lopes RB, Paraíba LC, Ceccarelli PS, Tornisielo VL. Bioconcentration of trichlorfon insecticide in pacu (Piaractus mesopotamicus). Chemosphere 2006;64:56-62. doi: 10.1016/j.chemosphere.2005.11.029

8. Lopes RM, Filho MV, de Salles JB, Bastos VL, Bastos JC. Cholinesterase activity of muscle tissue from freshwater fishes: Characterization and sensitivity analysis to the organophosphate methyl-paraoxon. Environ Toxicol Chem 2014;33:1331-6. doi: 10.1002/etc.2556

9. Malaqueiro MI, Nakaghi LS, Yamada PK, de Camargo Ferraz G, de Queiroz-Neto A, DeOliveira GH. Degradation, residual determination, and cholinesterase activity of triclorfon in Piaractus mesopotamicus Holmberg (PACU) 1887. J Toxicol Environ Health A 2014;77:125-32. doi: $10.1080 / 15287394.2013 .866928$

10. Castro MP, de Moraes FR, Fujimoto RY, da Cruz C, Belo MA, de Moraes JR. Acute toxicity by water containing hexavalent or trivalent chromium in native Brazilian fish, Piaractus mesopotamicus: anatomopathological alterations and mortality. Bull Environ Contam Toxicol 2014;92:213-9. doi: 10.1007/s00128-013-1174-5 
11. European Commission. Commission decision of 10 March 2004 concerning the non-inclusion of atrazine in Annex I to Council Directive 91/414/EEC and the withdrawal of authorisations for plant protection products containing this active substance, 2004/248/EC [displayed 10 March 2015]. Available at http://ec.europa.eu/food/plant/protection/ evaluation/existactive/oj_atrazine.pdf

12. BRASIL. Instituto Brasileiro de Geografia e Estatística. [Censo 2010, Cidades. Lavoura temporária, 2010 in Portuguese] [displayed 15 Jun 2014]. Available at http:// www.ibge.gov.br/cidadesat/

13. Associação Brasileira de Normas Técnicas (ABNT). NBR 15088. Ecotoxicologia aquática - Toxicidade aguda. Método de ensaio com peixes [Aquatic ecotoxicology - acute toxicity. Test method with fish, in Portuguese]. São Paulo: ABNT; 2011.

14. Organisation for Economic Co-operation and Development (OECD). Guidelines for the Testing of Chemicals, Section 2 Effects on Biotic Systems. Test No. 203: Fish, Acute Toxicity Test.Paris: OECD; 1992

15. Hamilton MA, Russo RC, Thurston V. Trimed SpearmanKarber method for estimating medial lethal concentrations in toxicity bioassays. Environ Sci Technol 1977;11:714-9. doi: 10.1021/es60130a004

16. Urban DJ, Cook NJ. Hazard Evaluation Division standard evaluation procedure: ecological risk assessment. U.S. EPA Publication 540/9-86-001. Washington (DC): U.S. EPA, Office of Pesticide Programs; 1986.

17. Goktepe I, Portier R, Ahmedna M. Ecological risk assessment of Neem based pesticides. J Environ Sci Health B 2004:39:311-20. doi: 10.1081/PFC-120030244

18. Commission of the European Communities (CEC). Technical guidance document in support of commission directive 93/67/EEC on risk assessment for new notified substances. Part II, environmental risk assessment. Luxembourg: Office for official publication of the European Communities; 2003.

19. Ellman GL, Courtney KD, Andres Jr V, Featherstone RM. A new and rapid colorimetric determination of acetylcholinesterase activity. Biochem Pharmacol 1961;7:8895. doi: 10.1016/0006-2952(61)90145-9

20. Villescas R, Oswald R, Marimoto H. Effects of neonatal undernutrition and cold stress on behavior and biochemical brain parameters in rats. J Nutr 1981;111:1103-10. PMID: 7241231

21. Hartley HO. Use of range in analysis of variance. Biometrika 1950;37:271-80. doi: 10.1093/biomet/37.3-4.271

22. BRASIL. Ministério do Meio Ambiente. Conselho Nacional do Meio Ambiente (CONAMA). [Resolução n. 357, de 17 de março de 2005. Dispõe sobre a classificação dos corpos de água e diretrizes ambientais para o seu enquadramento, bem como estabelece as condições e padrões de lançamento de efluentes, e dá outras providências, in Portuguese] [displayed 27 May 2014]. Available at http://www.mma.gov. br/port/conama/res/res05/res35705.pdf

23. Pissarra TCT, Politano W, Ferraudo AS. [Avaliação de características morfométricas na relação solo-superfície da Bacia Hidrográfica do Córrego Rico, Jaboticabal (SP), in Portuguese]. Rev Bras Ciênc Solo 2004;28:297-305.

24. Donadio NMM, Galbiatti JA, Paula RC. [Qualidade da água de nascentes com diferentes usos do solo na bacia hidrográfica do Córrego Rico, São Paulo, Brasil, in Portuguese]. Eng Agríc 2005;25:115-25.
25. Gish TJ, Prueger JH, Daughtry CS, Kustas WP, Mckee LG, Russ AL, Hatfield JL. Comparison of field-scale herbicide runoff and volatilization losses: an eight-year field investigation. J Environ Qual 2011;40:1432-42. doi: 10.2134/ jeq2010.0092

26. Armas ED, Monteiro RTR, Antunes PM, Santos MAPF, Camargo PB, Abakerli RB. [Diagnóstico espaço-temporal da ocorrência de herbicidas nas águas superficiais e sedimentos do Rio Corumbataí e principais afluentes, in Portuguese]. Quim Nova 2007;30:1119-27. doi: 10.1590/ S0100-40422007000500013

27. Azevedo DA, Gerchon E, Reis EO. Monitoring of pesticides and polycyclic aromatic hydrocarbons in water from Paraíba do Sul River, Brazilian. J Braz Chem Soc 2004;15:292-9. doi: 10.1590/S0103-50532004000200021

28. Bortoluzzi EC, Rheinheimer DS, Gonçalves CS, Pellegrini JBR, Maroneze AM, Kurz MHS, Bacar NM, Zanella R. Investigation of the occurrence of pesticide residues in rural wells and surface water following application to tobacco. Quím Nova 2007;30:1872-6. doi: 10.1590/S010040422007000800014

29. Kreutz LC, Barcellos LJG, Silva TO, Anziliero D, Martins D, Lorenson M, Marteninghe A, da Silva LB. Acute toxicity test of agricultural pesticides on silver catfish (Rhamdia quelen) fingerlings. Ciênc Rural 2008;38:1050-5. doi: 10.1590/S0103-84782008000400022

30. Solomon KR, Carr JA, Du Preez LH, Giesy JP, Kendall RJ, Smith EE, Van Der Kraak GJ. Effects of atrazine on fish, amphibians, and aquatic reptiles: a critical review. Crit Rev Toxicol 2008;38:721-72. doi: 10.1080/10408440802116496

31. Botelho RG, Santos JB, Oliveira TA, Braga RR, Byrro ECM. Toxicidade aguda de herbicidas a tilápia (Oreochromis niloticus) [Acute toxicity to herbicides to Oreochromis niloticus, in Portuguese]. Planta Daninha 2009;27:621-6. doi: 10.1590/S0100-83582009000300024

32. Saglio P, Trijasse S. Behavioral responses to atrazine and diuron in goldfish. Arch Environ Contam Toxicol 1998;35:484-91. PMID: 9732481

33. Xing H, Wu H, Sun G, Zhang Z, Xu S, Li S. Alterations in activity and mRNA expression of acetylcholinesterase in the liver, kidney and gill of common carp exposed to atrazine and chlorpyrifos. Environ Toxicol Pharmacol 2013;35:47-54. doi: 10.1016/j.etap.2012.11.004

34. Botelho RG, Rossi ML, Maranho LA, Olinda RA, Tornisielo VL. Evaluation of surface water quality using an ecotoxicological approach: a case study of the Piracicaba River (São Paulo, Brazil). Environ Sci Pollut Res Int 2013;20:4382-95. doi: 10.1007/s11356-013-1613-1

35. Moron S, Andrade C, Fernandes MN. Response of mucous cells of the gills of traíra (Hoplias malabaricus) and jeju (Hoplerythrinus unitaeniatus) (Teleostei: Erythrinidae) to hypo- and hyper-osmotic ion stress. Neotrop Ichthyol 2009;7:491-8. doi: 10.1590/S1679-62252009000300017

36. Botelho RG, Santos JB, Fernandes KM, Neves CA. Effects of atrazine and picloram on grass carp: acute toxicity and histological assessment. Toxicol Environ Chem 2012;94:1217. doi: $10.1080 / 02772248.2011 .633915$

37. Simonato JD, Guedes CLB, Martinez CBR. Biochemical, physiological, and histological changes in the neotropical fish Prochilodus lineatus exposed to diesel oil. Ecotoxicol Environ Saf 2008;69:112-20. doi: 10.1016/j. ecoenv.2007.01.012 
38. Dornelles MF, Oliveira GT. Effect of atrazine, glyphosate and quinclorac on biochemical parameters, lipid peroxidation and survival in bullfrog tadpoles (Lithobates catesbeianus). Arch Environ Contam Toxicol 2013;66:415-29. doi: 10.1007/ s00244-013-9967-4

39. Tabche LM, Oliván LG, Martinez MG, Castillo CR, Santiago AM. Toxicity of nickel in artificial sediment on acetylcholinesterase activity and hemoglobin concentration of the aquatic flea, Moina macrocopa. J Environ Hydrol 2000;8:1-10
40. Bretaud S, Toutant JP, Saglio P. Effects of carbofuran, diuron, and nicosulfuron on acetylcholinesterase activity in goldfish (Carassius auratus). Ecotoxicol Environ Saf 2000;47:11724. PMID: 11023689

41. Miron DS, Crestani M, Shettinger RM, Maria Morsch M, Baldisserotto B, Angel Tierno M, Moraes G, Vieira VL. Effects of the herbicides clomazone, quinclorac and metsulfuron methyl on acetylcholinesterase activity in the silver catfish (Rhamdia quelen) (Heptapteridae). Ecotoxicol Environ Saf 2005;61:398-403. PMID: 15922806

\section{Razine atrazina u vodotoku Jaboticabal (São Paulo, Brazil) i njihovi toksikološki učinci na ribu Piaractus mesopotamicus}

Predmet ovoga istraživanja bio je odrediti okolišne koncentracije atrazina u pet vodotoka na sjeveru brazilske savezne države São Paulo te ocijeniti njihove toksikološke učinke na ribu Piaractus mesopotamicus. Uzorci vode prikupljeni su u tri navrata između 2010. i 2011. godine, i to na početku, usred i pri kraju kišne sezone. Razine atrazina mjerene su trostrukim kvadrupolom s vezanim sustavom tekućinska kromatografija visoke djelotvornosti-spektrometrija mase (HPLCMS/MS). Potom je izračunat kvocijent okolišnog rizika $(\mathrm{QR})$ na temelju srednje smrtonosne koncentracije $\left(\mathrm{LC}_{50} 48 \mathrm{~h}\right)$, maksimalne koncentracije bez učinka (NOEC) te procijenjene okolišne koncentracije (EEC) atrazina pronađ̃enog $\mathrm{u}$ okolišu. Nadalje, istražene su histološke promjene u škrgama i jetri te izmjerena aktivnost enzima acetilkolinesteraze (AChE) u mozgu. Najviša izmjerena razina atrazina bila je $10.4 \mu \mathrm{g} \mathrm{L} \mathrm{L}^{-1}$. LC $\mathrm{C}_{0}(48 \mathrm{~h})$ atrazina za mlade jedinke $P$. mesopotamicus bio je $24.46 \mathrm{mg} \mathrm{L}^{-1}$, a QR je klasificiran kao „siguran“. Premda QR upućuje na to da bi se atrazin mogao okarakterizirati sigurnim za ispitanu vrstu, uzrokovao je ne samo brojne histološke promjene u jetri i škrgama izloženih jedinki, nego i porast razina AChE u mozgu. 